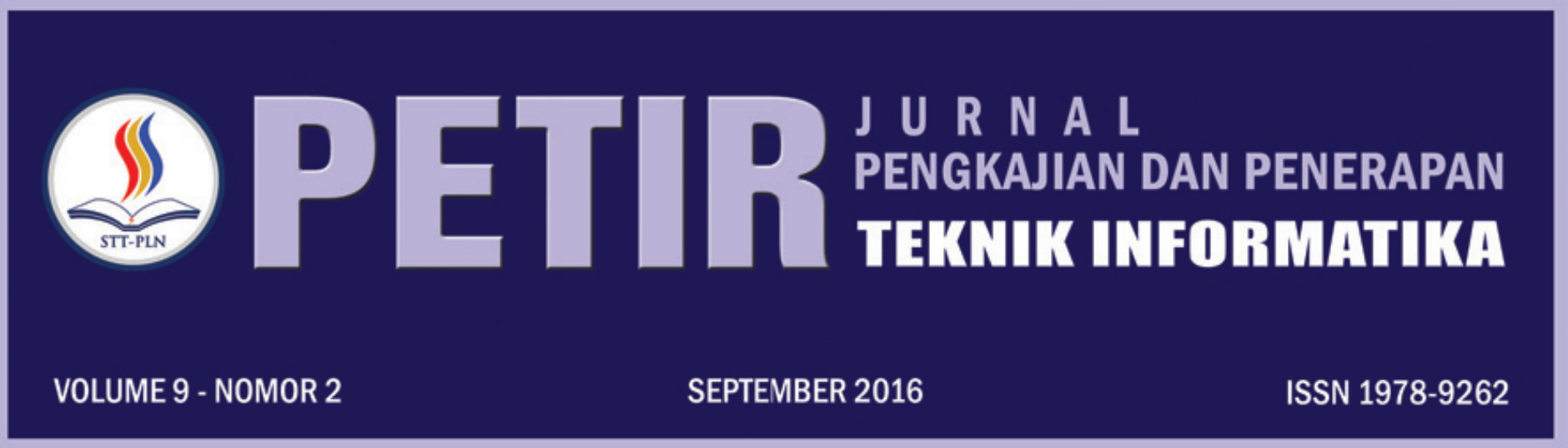

ANALISA SPASIAL UNTUK MELIHAT TINGKAT KESEJAHTERAAN MASYARAKAT DI PROVINSI BANTEN Muhamad Jafar Elly; Reza Pahlevi

PENENTUAN WILAYAH RAWAN PENYAKIT BERBASIS LINGKUNGAN DI JAKARTA TIMUR MENGGUNAKAN SISTEM INFORMASI GEOGRAFIS

Atiqah Meutia Hilda; Muhamad Jafar Elly; Windu Nugroho Cahyo Pamungkas

APLIKASI PENCARIAN USTADZ UNTUK WILAYAH DKI JAKARTA MENGGUNAKAN ALGORITMA HAVERSINE FORMULA BERBASIS ANDROID

Harni Kusniyati; Haries Fadhillah

PERENCANAAN ARSITEKTUR ENTERPRISE PERGURUAN TINGGI DENGAN PENDEKATAAN ENTERPRISE ARCHITECTURE PLANNING (EAP) (STUDI KASUS POLITEKNIK PIKSI GANESHA)

M. Farid Rifai

PERANCANGAN E-KATALOG PADA PERPUSTAKAAN DIGITAL STT-PLN BERBASIS WEB

Yessy Fitriani; Yasni Djamain; Risalatulina Dwi Kurniati

APLIKASI SISTEM GPS KEGIATAN OPERASIONAL PERSAMPAHAN DINAS PENGELOLAAN SAMPAH, PERTAMANAN DAN PEMAKAMAN (DP4) KOTA SUKABUMI

Yasmi Afrizal; Julian Chandra W
PERANCANGAN APLIKASI PENGOLAHAN DATA KAS BERBASIS ONLINE
(STUDI KASUS : KEMENTRIAN ' $X$ ')
Dian Hartanti; Lingga Desyanita

PERANCANGAN SISTEM INFORMASI PESERTA SERTIFIKASI

(Studi kasus LSP Piksi Ganesha)

Hendra Jatnika

RANCANG BANGUN APLIKASI SEC-WAY GUNA PENGINGAT BEPERGIAN DILENGKAPI INFO CUACA DAN CCTV JALAN RAYA LOKASI PILIHAN BERBASIS ANDROID STUDI KASUS DKI JAKARTA

Yasni Djamain; Intan Ratna Sari Yanti; Hari Wibowo

PREDIKSI PENERIMAAN SISWA BARU PADA MADRASAH ALIYAH AS-SAYAFI'IYAH 02 MENGGUNAKAN METODE TIME SERIES

Sarwo; Hermawan

PERANCANGAN SIMULASI MEDIA PEMBELAJARAN DENGAN METODE DIVISION REMAINDER UNTUK PENCARIAN ALAMAT RELATIF PADA PROSES PENEMPATAN DATA

Dewi Arianti Wulandari; Darma Rusjdi

ANALISIS SISTEM PENENTUAN LOKASI GANGGUAN JARINGAN DISTRIBUSI LISTRIK TERINTEGRASI GOOGLE MAP Abdul Haris; Herman Bedi Agtriadi

\begin{tabular}{|c|c|c|c|c|c|c|}
\hline \multirow{2}{*}{$\begin{array}{c}\text { ISSN } \\
|||||||||||||||||||||||||| \mid\end{array}$} & \multicolumn{6}{|c|}{ SEKOLAH TINGGI TEKNIK - PLN (STT-PLN) } \\
\hline & PETIR & VOL. 9 & NO. 2 & HAL. $89-166$ & JAKARTA, SEPTEMBER 2016 & ISSN 1978-9262 \\
\hline
\end{tabular}




\title{
PERANCANGAN SISTEM INFORMASI PESERTA SERTIFIKASI (Studi kasus LSP Piksi Ganesha)
}

\author{
Hendra Jatnika, S.Kom., M.Kom. \\ Jurusan Teknik Informatika \\ Sekolah Tinggi Teknik PLN Jakarta \\ Email :h.jatnika.sttpln@gmail.com
}

\begin{abstract}
Nowadays, profession or competency certification is started to be taken seriously by the society, especially the students. This certification is used, among others, to get an acknowledgement for the owned competency, increase the credibility, adding the selling point, and the opportunity to get a better career. Piksi Ganesha Certification Body as the organizer of the internal certification holds this mandatory-for-students' event every year. There are some obstacles in the certification data management, such as: data redundancy, temporary archieve storage, etc. These things are caused by the management is still using manual system and not using Computer-Based Information System (CBIS). A good and appropriate Computer-Based Information System design is needed in order to improve the effective and efficient performance, in giving the best service, data management, and also information provision for the certification participants.
\end{abstract}

Keywords: information system design, certification, management

\section{Abstrak}

Saat ini, masyarakat, khususnya peserta didik, mulai menyadari pentingnya sertifikasi profesi atau sertifikasi kompetensi sebagai bentuk pengakuan terhadap kompetensi yang dimiliki. Sertifikasi ini dilakukan untuk meningkatkan kredibilitas serta menambah nilai jual untuk berkarir. Lembaga Sertifikasi Piksi Ganesha sebagai pelaksana sertifikasi internal menyelenggarakan kegiatan sertifikasi setiap tahun dan bersifat wajib bagi peserta didiknya. Dalam pengelolaan data sertifikasi masih terdapat beberapa kelemahan, seperti: redudansi data, tempat penyimpanan arsip yang tidak dapat bertahan lama dan sebagainya. Hal ini diakibatkan karena belum digunakannya computer Based Information System (CBIS) atau Sistem Informasi Berbasis Komputer. Adanya rancangan Sistem Informasi Berbasis Komputer yang memadai, dirasa sangat penting untuk meningkatkan kinerja agar dapat lebih efektif dan efisien di dalam memberikan pelayanan, pengolahan data, serta penyediaan informasi bagi peserta sertifikasi.

Kata kunci: sistim informasi berbasis komputer, sertifikasi, manajemen

\section{PENDAHULUAN}

\subsection{Latar Belakang}

Saat ini, dunia pendidikan dan masyarakat pada umumnya mulai menyadari pentingnya sertifikasi atau uji kompetensi profesi dan kompetensi. Selain sebagai tanda bukti untuk mendapatkan pengakuan terhadap kompetensi yang dimiliki, juga untuk meningkatkan kredibilitas serta menambah nilai jual dan kesempatan berkarir lebih besar. Sertikasi juga memberi ukuran sejauh mana keahlian dan pengetahuan yang dimiliki baik bagi para pencari kerja, para profesional di setiap bidangnya maupun bagi mereka yang masih mengikuti pendidikan di tingkat menengah dan perguruan tinggi. Peningkatan pemahaman dan kesadaran masyarakat dan tenaga kerja akan arti pentingnya sertifikasi kompetensi kerja akan berdampak baik pada pengakuan serta penghargaan terhadap sertifikasi kompetensi, terutama menjawab tantangan pasar kerja global di masa masyarakat ekonomi asean dan yang akan datang.

Dengan didirikannya lembaga unit sertifikasi, menjadi pelaksana kegiatan sertifikasi profesi dan kompetensi melalui uji kompetensi yang mendapat tugas dari institusi secara langsung. Selain melaksanakan operasional unit sertifikasi juga memiliki fungsi mengembangkan standar kompetensi, dan memberikan sertifikat kompetensi. Unit sertifikasi melayani mahasiswa dan masyarakat profesional yang akan melaksanakan sertifikasi Kompetensi dan profesi, mulai dari pendaftaran peserta, pelaksanaan Uji Kompetensi, hingga pengambilan sertifikat.

Di dalam memberikan pelayanan serta penyediaan informasi bagi peserta sertifikasi (asesi), harus maksimal sehingga efektif dan efisien dan terorganisir dengan baik. Mengingat pentingnya pelayanan dan penyediaan informasi dalam meningkatkan kepuasan peserta sertifikasi, menggunakan sistem informasi secara terkomputerisasi sangat penting. Dari uraian diatas penulis merasa perlu membuat suatu rancangan sistem informasi untuk hal tersebut, sehingga diharapkan dengan adanya sistem yang tersebut akan membantu kinerja bagian operasional khususnya untuk proses pelayanan peserta sertifikasi, serta mampu menghasilkan informasi yang tepat bagi penggunanya 


\subsection{Rumusan Masalah}

Berdasarkan latar belakang diatas maka rumusan masalah dapat dibagi menjadi beberapa garis besar :

1. Bagaimana sistem Informasi pelayanan peserta sertifikasi yang sesuai dengan kebutuhan peserta (asesi) dan manajemen institusi ?

2. Bagaimana merancang aplikasi yang terkomputerisasi dengan baik yang dapat membantu user sebagai pengguna?

\subsection{Tujuan Penelitian}

Berdasarkan kepada latar belakang dan rumusan masalah diatas maka tujuan yang penulis dalam melakukan penelitian ini yaitu :

1. Untuk mengetahui sistem informasi yang sesuai dengan institusi yang berjalan saat ini serta estimasi kendala apa saja yang ditimbulkan.

2. Menghasilkan rancangan sistem informasi yang sesuai dengan kebutuhan unit sertifikasi

\subsection{Manfaat Penelitian}

1. Bagi Penulis

Manfaat yang diperoleh penulis untuk mengembangkan ilmu pengetahuan bidang sistem informasi, meningkatkan time management.

2. Institusi terkait

Dapat bermanfaat sebagai pertimbangan atau masukan bilamana mendirikan unit sertifikasi dan senantiasa meningkatkan kualitas sistem pengolahan dan penyimpanan data yang cepat dan akurat sehingga memudahkan pengaksesan informasi yang dibutuhkan.

3. Bagi Pembaca

Dapat dijadikan referensi dan menambah ilmu yang dapat dimanfaatkan dan dikembangkan lebih lanjut, serta menambah wawasan dalam bidang sistem informasi khususnya dalam dalam perancangan sistem informasi

\section{LANDASAN TEORI}

\subsection{Perancangan Dialog Layar}

Perancangan dialog layar monitor merupakan rancang bangun dari percakapan antara pemakai dan komputer. Percakapan ini dapat berupa :

1. Proses memasukan data

2. Proses menampilkan output informasi

Pedoman perancangan dialog layar secara terinci adalah :

1. Pemakai harus dipandu bagaimana melakukan langkah selanjutnya

2. Layar dialog harus informatif, misal dengan cara pembagian bentuk jendela yang meliputi : jendela judul, jendela instruksi, jendela tubuh, serta jendela escape.

3. Dalam jendela tubuh dialog seharusnya dibatasi untuk satu ide saja tiap framenya.

4. Pagging \& Scrolling dapat digunakan untuk menampilkan jendela tubuh

5. Berita, instruksi, atau informasi yang ditampilkan di layar ditampilkan dalam waktu cukup lama agar pemakai dapat mempunyai cukup waktu untuk membacanya.
6. Gunakan kalimat/istilah yang sederhana dan mudah dipahami

7. Penggunaan singkatan sebaiknya dihindari

8. Penggunaan simbol yang membingungkan harus dihindari

9. Penggunaan kata yang konsisten ( misal : EDIT, UPDATE, KOREKSI )

a. Beberapa strategi perancangan dialog layar monitor dapat digunakan secara terpisah atau bersama-sama yaitu :

10. Tampilan menu

11. Kumpulan instruksi (instruction sets)

12. Dialog pertanyaan/jawaban ( question/answer dialog )

13. Penggunaan bagan dialog untuk tampilan layar dialog yang sangat banyak

14. Penggunaan bagan tata letak layar monitor

15. Penjelasan data di kamus data dialog

\subsection{Pengertian Istilah Sistem Informasi}

1. Sistem ( Sistem Abstrak dan Sistem Fisik) Drs, Moekijat, Pengantar sistem informasi manajemen. Penerbit PT. Remaja Karya CV dapat dipahami bahwa Sistem dapat abstrak atau fisis. Sistem yang abstrak adalah susunan yang teratur dari gagasan-gagasan atau konsepsi-konsepsi yang saling tergantung. Misalnya, sistem teologi adalah susunan yang teratur dari gagasan-gagasan tentang Tuhan, manusia, dan sebagainya. Sistem yang bersifat fisis adalah serangkaian unsur yang bekerja sama untuk mencapai suatu tujuan.

Untuk menjelaskan sistem yang bersifat fisis, contoh antara lain sebagai berikut : Sistem angkutan - pegawai-pegawai, mesin-mesin, dan organisasi yang mengangkut barang-barang. Sistem sekolah - gedung-gedung, guru-guru, administrator-administrator, buku-buku pelajaran, dan sebagainya yang bersama-sama berfungsi memberikan pelajaran kepada para siswa.

Edhy Sutanta, Sistem Informasi Manajemen, Penerbit Graha IImu sistem terdiri atas kegiatankegiatan yang berhubungan guna mencapai tujuantujuan perusahaan seperti pengendalian inventaris atau penjadwalan produksi.

Robert G. Murdick/ Joel E. Ross, Sistem Informasi untuk manajemen Modern. Penerbit PT. Erlangga dapat disimpulkan sistem terdiri atas obyek-obyek, atau unsur-unsur, atau komponenkomponen yang bertata-kaitan dan bertatahubungan satu sama lain sedemikian rupa sehingga unsur-unsur tersebut merupakan suatu kesatuan pemrosesan atau pengolahan uang tertentu

Suatu sistem akan didefinisikan sebagai suatu gugus komponen-komponen yang dirancang untuk menyelesaikan suatu tujuan tertentu sesuai dengan rencana. Terdapat tiga hal yang penting dalam definisi ini, Pertama, adanya maksud atau tujuan, dimana sistem dirancang untuk mengerjakannya. Kedua, adanya suatu rancangan, atau suatu susunan komponen-komponen. Akhirnya input informasi, energi (tenaga), dan bahan-bahan (material) harus dialokasikan sesuai dengan rencana. 
2. Sistem Deterministik dan Sistem Probabilistik

Sistem deterministik (deterministic system) adalah suatu sistem yang operasinya dapat diprediksi secara tepat, misalnya sistem komputer. Sedangkan sistem probabilistik (probabilistic system) adalah sistem yang tak dapat diramal dengan pasti karena mengandung unsur probabilitas, misalnya sistem arisan dan sistem sediaan, kebutuhan rata-rata dan waktu untuk memulihkan jumlah sediaan dapat ditentukan tetapi nilai yang tepat sesaat tidak dapat ditentukan dengan pasti.

\section{Sistem Tertutup dan Sistem Terbuka}

Sistem tertutup (closed system) adalah sistem yang tidak bertukar materi, informasi, atau energi dengan lingkungan, dengan kata lain sistem ini tidak berinteraksi dan tidak dipengaruhi oleh lingkungan, misalnya reaksi kimia dalam tabung yang terisolasi. Sedangkan sistem terbuka (open system) adalah sistem yang berhubungan dengan lingkungan dan dipengaruhi oleh lingkungan, misalnya sistem perusahaan dagang.

4. Sistem Alamiah dan Sistem Buatan Manusia Sistem Alamiah (natural system) adalah sistem yang terjadi karena alam, misalnya sistem tata surya. Sedangkan sistem buatan manusia (human made system) adalah sistem yang dibuat oleh manusia,misalnya sistem komputer.

5. Sistem Sederhana dan Sistem Kompleks

Berdasarkan tingkat kerumitannya, sistem dibedakan menjadi sistem sederhana (misalnya sepeda) dan sistem kompleks (misalnya otak manusia).

\subsection{Perancangan Model}

Perancangan sistem atau model adalah bagaimana mengorganisasikan sistem ke dalam subsistem-subsistem, serta alokasi subsistemsubsistem ke komponen-komponen perangkat keras, perangkat lunak, serta prosedur-prosedur. Perancangan model SIM dapat dibedakan menjadi dua, yaitu :

1. Pembuatan model logik (logical moden)

2. Model fisik sistem (physical model)

Model logik digunakan untuk menjelaskan secara logik kepada pemakai tentang bagaimana fungsi-fungsi dalam SIM akan bekerja. Model logik dapat digunakan dengan menggunakan Diagram Arus Data /DAD (Data Flow Diagram/DFD)

Model fisik digunakan untuk menjelaskan kepada pemakai tentang bagaimana sistem secara fisik akan diterapkan. Bagan alir system (system flowchart) merupakan alat yang tepat untuk menunjukkan simbol fisik yang digunakan, seperti terminal, media penyimpan, laporan dan sebagainya. Bagan alir data merupakan alat berbentuk grafis yang digunakan untuk menggambarkan aliran pemroses dalam SIM berbasis komputer.

\subsection{Perancangan Basis Data}

Perancangan basis data secara umum dilakukan dengan menentukan kebutuhankebutuhan file-file dalam basis data berdasarkan DAD sistem baru yang telah dibuat dan kemudian menentukan parameter file dalam basis data.

Beberapa hal penting yang perlu diperhatikan dalam rancangan basis data adalah :

1. Minimalisasi kerangkapan data (data redundancy)

2. Dihindari terjadinya inkonsistensi data (inconsistency data)

3. Data-data dalam basis data harus dapat digunakan secara bersama-sama (share ability )

4. Standarisasi data yntuk menyeimbangkan perbedaan kebutuhan data para pemakai

5. Pembatasan kewenangan (privacy) dan keamanan data (data security)

6. Menjamin integritas data (data integrity)

7. Menghindari terjadinya data terisolasi ( data isolation )

8. Berorientasi pada data ( data oriented) dan bukan pada program ( program oriented)

9. Data dapat digunakan oleh pemakai-pemakai yang berbeda atau beberapa program aplikasi tanpa perlu mengubah basis data

10. Data dapat berkembang dengan mudah baik volume maupun strukturnya

11. Data yang ada dapat memenuhi kebutuhan sistem-sistem secara mudah

12. Data dapat digunakan dengan cara yang berbeda-beda

13. Independensi data ( data indepency), baik secara logik maupun secara fisik

14. Dihindari terjadinya penyimpangan ( anomaly ) dalam basis data

\subsection{Perancangan Teknologi}

Secara umum, teknologi SIM adalahateknologi komputer yang dikelompokan menjadi tiga klasifikasi, yaitu :

1. Teknologi Perangkat Keras

Teknologi perangkat keras untuk SIM adalah teknologi komputer. Secara umum, sistem komputer mempunyai komponen perangkat keras yang terdiri atas :

Perangkat keras masukan, terdiri dari :

a. Alat input langsung

b. Alat input tidak langsung

Contoh perangkar keras masukan adalah : keyboard, teleprinter terminal, dll.

Perangkat keras keluaran. Terdiri atas :

a. Hard copy device, contoh: printer, plotter, dll.

b. Soft copy device, contoh : video display, speaker, dll.

c. Drive device, contoh : disk drive, cd drive, dll. Perangkat keras unit pengolah atau Central Processing Unit (CPU) terdiri atas :

a. Aritmatic and Logic Unit ( ALU )

b. Control Unit

c. Main Memory ( RAM dan ROM )

2. Teknologi Perangkat Lunak

a. Kategori perangkat lumak

Perangkat lunak dapat dikategorikan dalam tiga bagian yaitu : 
1) Perangkat lunak sistem operasi ( Operating System/OS ), yaitu program yang ditulis untuk mengendalikan dan mengkoordinasi kegiatan dari perangkat keras sistem komputer

2) Perangkat lunak bahasa ( Language Software ), yaitu program yang digunakan untuk menterjemahkan intruksi-intruksi yang ditulis dalam bahasa pemrograman ke dalam bahasa mesin supaya dimengerti komputer

3) Perangkat lunak aplikasi ( Aplication Software ), yaitu program yang ditulis dan diterjemahkan oleh Language Software untuk menyelesaikan suatu aplikasi tertentu.

b. Sistem Operasi (Operating System/OS)

Sistem operasi merupakan program yang ditulis untuk mengendalikan dan mengkoordinasi kegiatan dari sistem komputer.

c. Control Program

Control program umumnya sebagian disimpan di main memori tepatnya di ROM dan disebut juga dengan resident program atau resident routine.

\subsection{Perancangan Sistem Informasi}

Design system adalah suatu proses menentukan bagaimana suatu sistem akan menyelesaikan apa yang mesti diselesaikan tahap ini menyangkut mengkonfigurasikan dari komponen-komponan perangkat lunak dan perangkat keras dari suatu sistem sehingga setelah instalasi dari sistem akan benar-benar memuaskan rancang bangun yang telah ditetapkan pada akhir analisis sistem. Pendapat George memberikan pengertian bahwa pada desain sistem ada dua kegiatan penting yaitu kegiatan menentukan bagaimana sistem akan dikembangkan dan kegiatan yang lain adalah kegiatan mengkonfigurasikan perangkat lunak dan perangkat keras untuk mendapatkan pemecahan masalah yang maksimal. Perancangan system adalah strategi tingkat tinggi untuk membuat keputusan-keputusan berikut :

1. pengorganisasian system menjadi subsistemsubsistem

2. Alokasi subsistem ke komponen-komponen perangkat keras dan perangkat lunak

3. Keputusan-keputusan konseptual dan kebijaksanaan utama untuk membentuk kerangka kerja rancangan rinci.

Dari penjelasan diatas maka dapat disimpulkan bahwa perancangan sistem informasi adalah suatu tahapan kegiatan yang dilakukan seseorang atau kelompok dalam merancang atau membuat sistem sebelum sistem dibuat dengan tujuan sistem yang dibangun sesuai dengan kebutuhan dalam memcahkan atau dengan kebutuhan pengguna berkaitan dengan pengolahan, pengelolaan dan perolehan informasi yang diinginkan.

\subsection{Peserta}

Pengertian Peserta ialah orang yg ikut serta atau yg mengambil bagian misal dalam kongres, seminar, lokakarya, pertandingan maupun tes uji kompetensi.

\subsection{Sertifikasi Kompetensi}

Sertifikasi Kompetensi adalah proses pemberian sertifikat kompetensi yang dilakukan secara sistematis dan obyektif melalui uji kompetensi yang mengacu kepada standar kompetensi kerja nasional Indonesia atau regional atau internasional. Sertifikat Kompetensi adalah bukti pengakuan tertulis atas penguasaan kompetensi kerja pada jenis profesi tertentu yang diberikan oleh Lembaga Sertifikasi Profesi, Badan Nasional Sertifikasi Profesi atau Intitusi tertentu yang menyelenggarakan kegiatan sesrtifikasi tertentu sesuai dengan kurikulum atau aturan yang berlaku.

\subsection{Standar Kompetensi Kerja Nasional Indonesia}

Standar Kompetensi Kerja Nasional Indonesia yang selanjutnya disingkat SKKNI adalah rumusan kemampuan kerja yang mencakup aspek pengetahuan, keterampilan dan atau keahlian serta sikap kerja yang relevan dengan pelaksanaan tugas dan syarat jabatan yang ditetapkan sesuai dengan ketentuan peraturan perundang-undangan yang berlaku.

\subsection{Kerangka Kualifikasi Nasional Indonesia}

Kerangka Kualifikasi Nasional Indonesia yang selanjutnya disingkat $\mathrm{KKNI}$ adalah kerangka penjenjangan kualifikasi kompetensi yang memungkinkan penyetaraan dan pengintegrasian antara jalur pendidikan, pelatihan kerja dan pengalaman kerja dalam rangka pemberian pengakuan dan penghargaan profesi.

\subsection{Uji Kompetensi}

Uji kompetensi adalah suatu sarana untuk menguji kemampuan siswa apakah siswa ini kompeten atau tidak kompeten di dalam mata diklat yang telah diberikan.

\subsection{Asesor Kompetensi}

Asesor Kompetensi adalah seseorang yang memiliki kompetensi dan memenuhi persyaratan untuk melakukan uji kompetensi pada jenis dan kualifikasi profesi tertentu.

\section{METODOLOGI PENELITIAN}

Prototyping paradigma dimulai dengan pengumpulan kebutuhan. Pengembang dan pelanggan bertemu dan mendefinisikan obyektif keseluruhan dari software, mengidentifikasi segala kebutuhan yang diketahui, dan area garis besar diman definisi lebih jauh merupakan keharusan kemudian dilakukan "perancangan kilat". Perancangan kilat berfokus pada penyajian dari aspek - aspek software tersebut yang akan nampak bagi pelanggan atau pemakai (contohnya pendekatan input dan format output) 


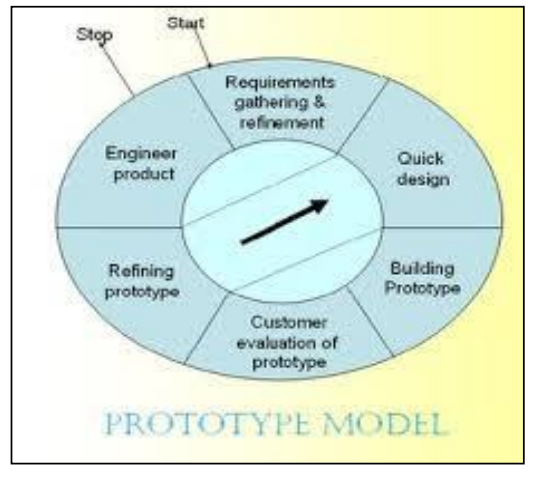

Gambar 1. Prototyping Model

Tahapan -tahapan dalam prototyping tersebut adalah sebagai berikut :

1. Pengumpulan kebutuhan Pelanggan dan pengembang bersama-sama mendefinisikan format dan kebutuhan kesseluruhan perangkat lunak, mengidentifikasikan semua kebutuhan, dan garis besar sistem yang akan dibuat.

2. Membangun prototyping dengan membuat perancangan sementara yang berpusat pada penyajian kepada pelanggan (misalnya dengan membuat input dan contoh outputnya).

3. Evaluasi ini dilakukan oleh pelanggan apakah prototyping yang sudah dibangun sudah sesuai dengan keinginan pelanggan. Jika sudah sesuai maka langkah keempat akan diambil. Jika tidak, maka prototyping diperbaiki dengan mengulang langkah 1,2 , dan 3.

4. Mengkodekan system Dalam tahap ini prototyping yang sudah disepakati diterjemahkan ke dalam bahasa pemrograman yang sesuai.

5. Menguji system Setelah sistem sudah menjadi suatu perangkat lunak yang siap pakai, harus dites dahulu sebelum digunakan. Pengujian ini dilakukan dengan White Box, Black Box, Basis Path, pengujian arsitektur dan lain-lain.

6. Evaluasi Sistem Pelanggan mengevaluasi apakah sistem yang sudah jadi sudah sesuai dengan yang diharapkan . Jika sudah, maka langkah ketujuh dilakukan, jika belum maka mengulangi langkah 4 dan 5 .

7. Menggunakan system Perangkat lunak yang telah diuji dan diterima pelanggan siap untuk digunakan

\section{HASIL DAN PEMBAHASAN}

\subsection{Perancangan Sistem Informasi Sertifikasi} di LSP Piksi Ganesha

Perancangan Sistem Informasi Pelayanan di LSP Piksi Ganesha ini berfungsi untuk mengolah data master yang terdiri dari data peserta, data asesor dan data nilai untuk diolah menjadi data jadwal ujikom dan hasil nilai Ujikom sehingga menjadi suatu laporan berupa :
1. Berita Acara Ujikom

2. Laporan kegiatan sertifikasi

\section{D.2. Flowmap Sistem yang diusulkan}

Flowmap ini menggambarkan aliran dokumen antar entitas baik itu entitas dalam maupun entitas luar yang berfungsi untuk menjelaskan hubungan sistem/entitas dalam yang sedang berjalan dengan entitas luar.

Flowmap yang akan dirancang adalah sebagai berikut :

1. Flowmap Pendaftaran Sertifikasi

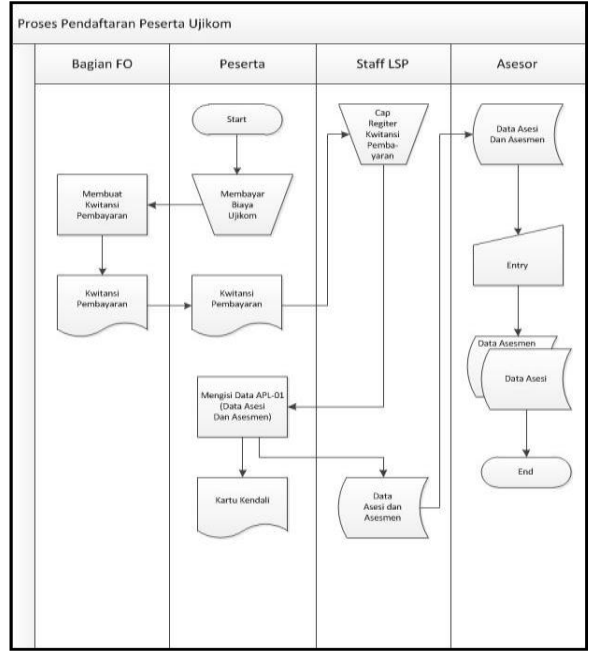

Gambar 2. Flowmap Pendaftaran

2. Flowmap Pelaksanaan dan Penilaian

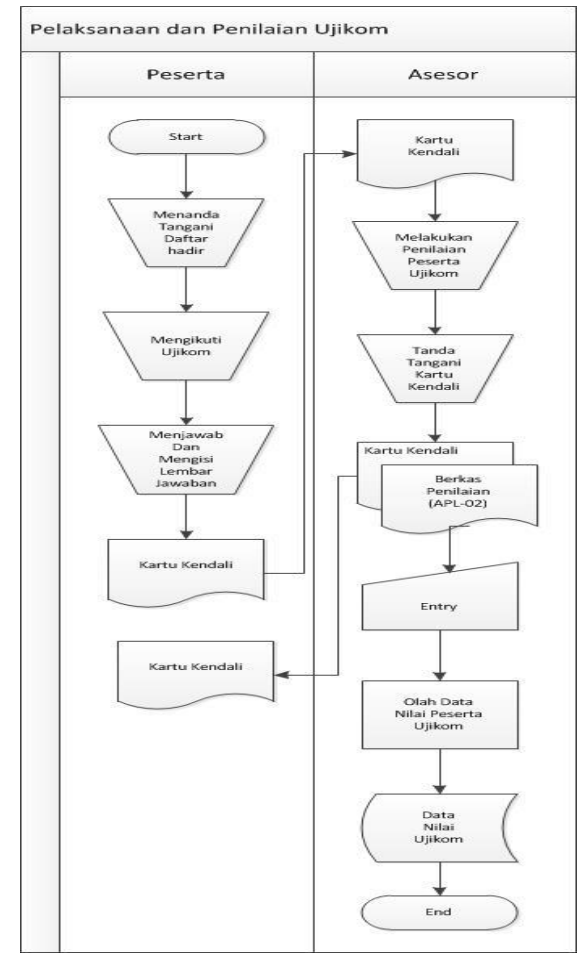

Gambar 3. Flowmap Pelaksanaan dan Penilaian sertifikasi 
3. Flowmap Pengambilan Sertifikat

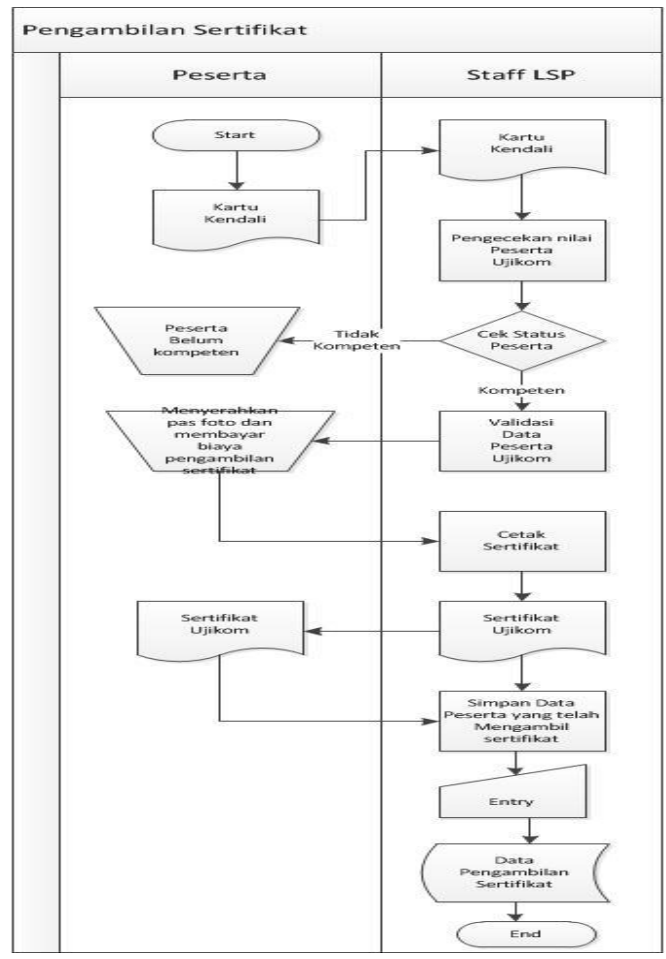

Gambar 4. Flowmap pengambilan sertifikat

\subsection{Diagram Konteks}

Entitas yang terdapat dalam Proses sama dengan sistem lama, yang berbeda adalah alur data dan prosesnya.

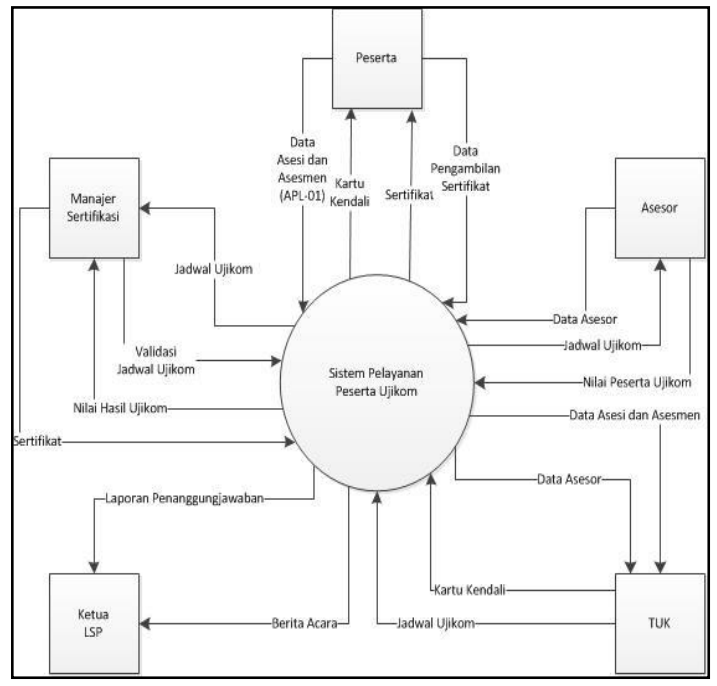

Gambar 5. Context Diagram Sistem sertifikasi

Konteks diagram diatas menggambarkan alur sistem informasi pelayanan peserta Ujikom di Lembaga Sertifikasi Politeknik Piksi Ganesha serta menggambarkan hubungan antar entitas yang terlibat dalam sistem yang akan dibuat.

\subsection{Data Flow Diagram}

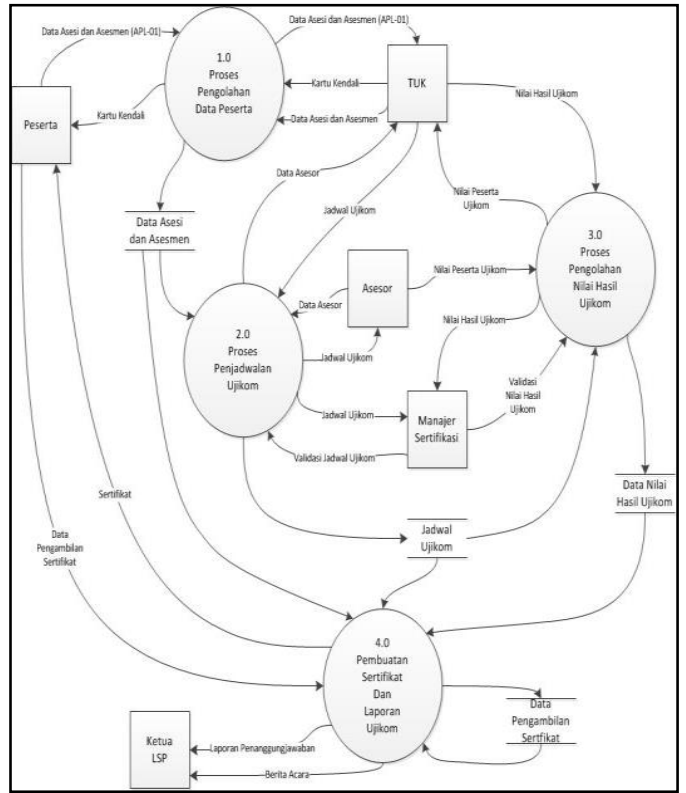

Gambar 6. Data Flow Diagram Diagram Sistem sertifikasi

DFD level 0 merupakan penjabaran dari Context Diagram. Dalam sebuah sistem informasi pelayanan yang digambarkan dalam Context Diagram terdapat 4 proses yaitu Proses Pengolahan Data Peserta, Proses Penjadwalam, Pengolahan Nilai Hasil Ujikom, Proses Pembuatan Sertifikat dan Laporan. Di dalam diagram level inilah memuat penyimpanan data (data store). Data Store yang digunakan dalam sistem Informasi Pelayanan Peserta Ujikom ini mencakup Data Peserta Ujikom, Jadwal Ujikom, Nilai Hasil Ujikom dan Data Pengambilan Sertifikat.

\subsection{Perancangan Basis Data}

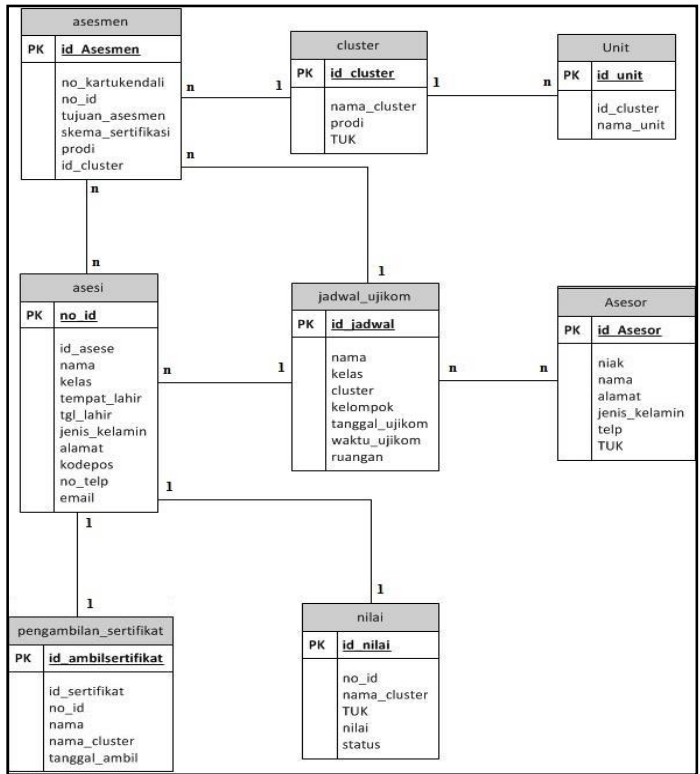

Gambar 7. Perancangan Basis Data Sertifikasi 


\subsection{Peracangan Interface}

1. Menu Aplikasi Sertifikasi

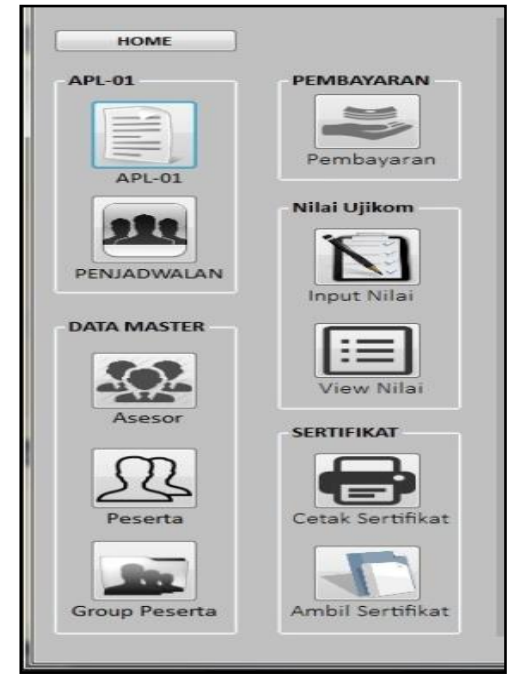

Gambar 8. Perancangan Menu Sertifikasi

2. Menu data olah peserta sertifikasi

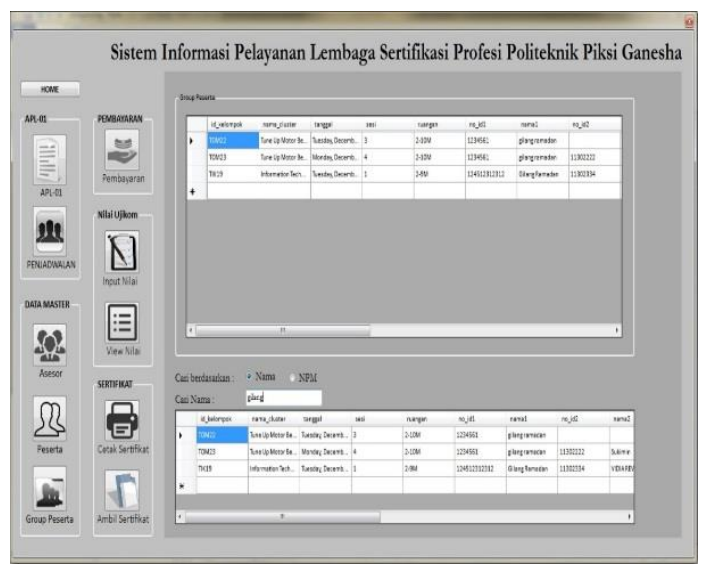

Gambar 9. Rancagan Interface data peserta Sertifikasi

3. Menu data hasil nilai sertifikasi peserta

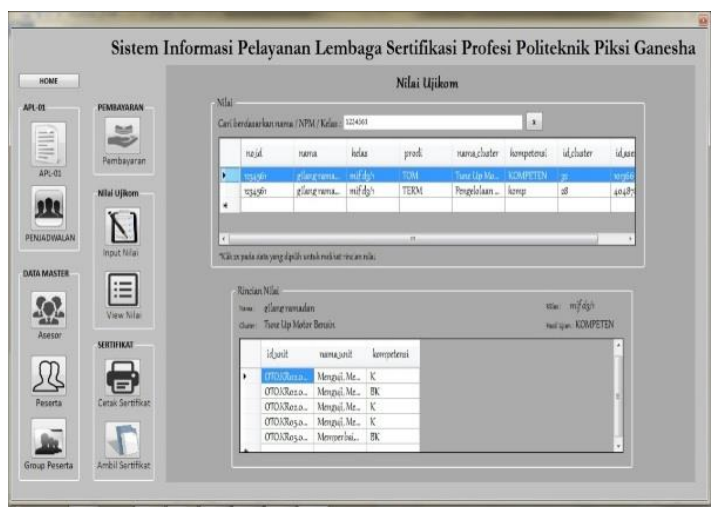

Gambar 10. Rancagan tampilan nilai/hasil sertifikasi
4. Menu cetak sertifikat peserta sertifikasi

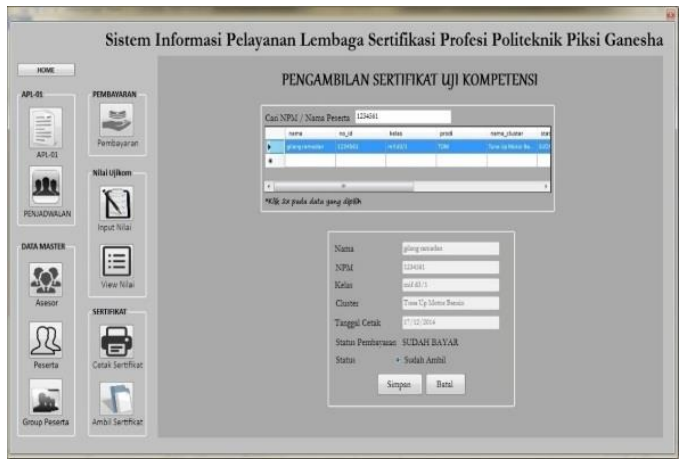

Gambar 11. Rancagan Interface cetak sertifikat

\section{KESIMPULAN}

Kesimpulan ini pada dasarnya merupakan jawaban dari identifikasi yang telah dikembangkan dari hasil analisis dan perancangan yang telah dilakukan dapat diambil kesimpulan sebagai berikut

1. Dengan program aplikasi pelayanan yang sistem informasinya terintegrasi memudahkan dan mempercepat pengguna (user) dalam pengolahan data peserta, sertifikasi

2. Dengan adanya rancanngan aplikasi ini dapat membantu user dalam pengolahan data sertifikasi.

\section{DAFTAR PUSTAKA}

1. Abdul Kadir, Konsep dan tuntutan Praktis Basis Data, Penerbit Andi Yogyakarta

2. Abdul Kadir, Dasar Perancangan dan Implementasi Database Relational, Penerbit Andi Yogyakarta

3. Drs, Moekijat, Pengantar sistem informasi manajemen. Penerbit PT. Remaja Karya CV

4. Edhy Sutanta, Sistem Informasi Manajemen, Penerbit Graha IImu

5. Ir. Harianto Kristanto, Konsep dan perancangan Database, Penerbit Andi Offset Yogyakarta

6. Robert G. Murdick/ Joel E. Ross, Sistem Informasi untuk manajemen Modern. Penerbit PT. Erlangga 